\title{
KERJASAMA ANTAR DAERAH DALAM PENGELOLAAN TEMPAT PEMEROSESAN AKHIR SAMPAH REGIONAL DI KAWASAN BANJAR BAKULA PROVINSI KALIMANTAN SELATAN
}

\author{
Irawanto \\ STIA Bina Banua Banjarmasin \\ irawanto67@gmail.com
}

\begin{abstract}
Cooperation between regions be crucial at the moment, having no the isolated and needs independently. The relationship between the government especially in the metropolitan have specific characteristics dynamic and develop to governance in its own, especially in the management of the regional pemerosesan garbage (tpa regional) in urban areas banjar bakula, south kalimantan. A policy of development program or project that involves many regions need to the arrangement institutional of government good involved so the program the cooperation it is efficiently and effectively, but in their implementation many obstacles related to the relationship between the government will be reference in have a partnership between regions
\end{abstract}

Keywords: Metropolitan Area, Cooperation Between The Regions. Banjar Bakula, South Kalimantan. 


\section{PENDAHULUAN}

Di era Desentralisasi dan otonomi daerah saat ini kerjasama antar daerah merupakan kunci keberhasilan pembangunan, karena kerjasama menjadi jembatan yang dapat mengubah potensi konflik kepentingan antar daerah menjadi sebuah potensi pembangunan yang sangat menguntungkan (Tarigan, 2009:1). Kerjasama antar daerah merupakan langkah sinergi di lingkungan pemerintahan dalam peningkatan pembangunan dan model ini menjadi suatu terobosan di berbagai belahan dunia, sebagaimana diungkap oleh Hulst et al., (2009), ia mengatakan kerjasama antar-kota adalah fenomena yang terjadi di negara-negara Eropa Barat saat ini. Hal ini juga dikatakan oleh Muttalib (1982), sebagai bagian dari suatu negara, pemerintah lokal menjadi patner pemerintah dalam pembangunan nasional.

Kota Banjarmasin dengan empat kabupaten/kota lainnya (Kota Banjarbaru, Kabupaten Banjar, Kabupaten Barito Kuala dan Kabupaten Tanah laut) termasuk kawasan Perkotaan dan daerah ini dinamakan kawasan metropolitan Banjar Bakula. Kawasan metropolitan Banjar Bakula ini memiliki jumlah penduduk sejumlah 1.980 .206 jiwa atau 52,25\% dari jumlah penduduk di 13 kabupaten/kota di Kalsel (BPS Kalsel 2012), dan wilayah ini lebih maju dibanding dengan daerah-daerah lainnya di Kalimantan Selatan.

Masalah sampah menjadi issu yang semakin mendesak untuk ditangani di kawasan ini. Pertumbuhan penduduk dan aktivitas sosial ekonomi di kawasan ini mempunyai korelasi positif terhadap peningkatan jumlah dan jenis sampah. Kondisi ini tentu akan mengancam ekosistem wilayah. Dalam Statistik Persampahan 2008 yang di laporkan Kementerian Negara Lingkungan Hidup menunjukkan bahwa total timbunan sampah di Indonesia sebesar 38,5 juta ton/tahun dengan komposisi $58 \%$ sampah dapur, $14 \%$ plastik, $9 \%$ kertas dan $19 \%$ sampah lainnya. Dari total sampah tersebut, sekitar 14,1 juta ton atau $36 \%$ merupakan sampah di kota besar dan metropolitan. (London, 2013:4)

Untuk mengatasi masalah sampah di kawasan Banjar Bakula dibutuhkan bentuk manajemen dengan pendekatan pemerintahan. Salah satu pendekatan pemerintahan untuk wilayah metropolitan adalah kerjasama intermunicipal (IMC). "IMC telah dibahas untuk waktu yang lama sebagai salah satu solusi untuk perbaikan tata kelola metropolitan" Ostrom 1991; Barlow 1991; Norris, Phares, dan Zimmerman 2007 Swianiewicz. (2011).

Pemerintah juga telah mengeluarkan Undang Undang RI No. 18/2008 tentang Pengelolaan Sampah yang mengamanatkan adanya kerjasama dan kemitraan antar pemerintah daerah, badan usaha dan masyarakat dalam melakukan pengelolaan sampah. Sebagaimana yang diungkapkan oleh Kurtz (2006)."kerjasama antar pemerintah adalah masa depan untuk sukses di pemerintah daerahsecara keseluruhan yang terkait dengan faktor ekonomi dan efektivitas .

Langkah penyelesaian masalah sampah dikawasan ini telah diupayakan oleh Pemerintah terlihat dari hasil penilaian yang dilakukan oleh Kementrian Pekerjaan Umum, Direktorat Jenderal Cipta Karya, dan PT Arkonin Engineering Manggala Pratama, Tahun 2010, terhadap tiga TPA yang ada di Kabupaten Banjar, Kota Banjarbaru dan Banjarmasin, maka TPA Hutan Panjang yang ada di Kota Banjarbaru, mendapat nilai tertinggi untuk dijadikan TPA Regional namun dengan syarat TPA Hutan Panjang harus menambah luas lahan. Tabel berikut ini menggambarkan kemampuan penanganan sampah di tiga TPA

Tabel : Kemampuan Penanganan Sampah di Tiga daerah di kawasan Banjar Bakula

\begin{tabular}{|l|l|l|l|l|}
\hline No & Indikator & Banjarmasin & Banjarbaru & Banjar \\
\hline 1 & Jumlah penduduk (Jiwa) & 705.575 & 184.487 & 222.694 \\
\hline 2 & Jumlah Penduduk terlayani (Jiwa) & 317.509 & 110.692 & 122.481 \\
\hline 3 & Jml Penduduk terlayani dalam \% & $45 \%$ & $60 \%$ & $55 \%$ \\
\hline 4 & Jlh timbulan Sampah $\left(\mathrm{M}^{3} /\right.$ hari) & 1.940 & 461 & 557 \\
\hline 5 & Jlh Sampah terlayani $\left(\mathrm{M}^{3} /\right.$ hari) & 837 & 277 & 306 \\
\hline 6 & Luas Wilayah $\left(\mathrm{Km}^{2}\right)$ & 72,67 & 328,83 & 4710,97 \\
\hline
\end{tabular}

Sumber : Master Plan TPA Regional Kota Banjarmasin, Kabupaten Banjar 2010 
Kerjasama antar daerah dalam penanganan dan pengelolaan sampah di kawasan Banjar Bakula menjadi persoalan yang mendesak. Dalam Penyelesaian masalah bersama tersebut sudah barang tentu harus dilakukan dengan prinsip saling menguntungkan.Atas dasar uraian permasalahan yang dipaparkan maka problem statement penelitian ini adalah Bagaimana kerjasama antar daerah dalam pengelolaan sampah di Kawasan Metropolitan Banjar Bakula. Adapun yang menjadi research questions sebagai berikut : 1) Bagaimana hubungan antar susunan pemerintah dalam pengelolaan Tempat Pemerosesan Akhir Sampah Regional. 2) Bagaimana model hubungan antar daerah dalam melakukan kerjasama dalam pengelolaan TPA Regional

\section{Konsep Hubungan antar Susunan Pemerintahan}

Dalam kerjasama antar daerah tidak terlepas sebenarnya bagaimana hubungan antar susunan pemerintahan. Wright (1982) membagi membagi model hubungan pemerintahan dalam 3 (tiga) model, yaitu :1) Coordinate Authority Model.Model ini dicirikan dengan hubungan antar pemerintah, dengan batas-batas yang tegas antara pemerintah pusat dengan pemerintah provinsi. Pemerintah kabupaten/kota sangat tergantung pada pemerintah provinsi yang otonom. 2) Inclusive Authority Model, Model ini dicirikan dengan kekuatan yang proporsional antara tingkat pemerintahan dan diantara tingkat pemerintahan tersebut terjadi saling menghormati. Hubungan yang terjadi dimana pemerintah provinsi dengan pemerintah kabupaten/kota, menjadi "pelayan" pemerintah pusat. 3) Overlapping Authority Model.Pada model ini, terdapat proses "tawar menawar" antara pemerintah pusat dengan pemerintah provinsi dan pemerintah kabupaten/kota. Pemerintah pusat menawarkan suatu program kepada pemerintah provinsi dan pemerintah kabupaten/kota, dan pemerintah provinsi atau pemerintah kabupaten/kota dapat menerimanya dengan memenuhi persyaratan yang diterapkan pemerintah pusat. Dalam melaksanakan pembangunan, suatu wilayah pemerintah daerah akan berpengaruh terhadap pemerintah daerah lainnya.

Dalam melaksanakan pembangunan, suatu wilayah pemerintah daerah akan berpengaruh terhadap pemerintah daerah lainnya. Oleh karena itu, hubungan antar pemerintah akan terjadi dalam proses pembangunan tesebut. Deil Wright (1978) mengungkapkan bahwa untuk mencapai hubungan antar pemerintah perlu diperhatikan lima unsur khusus. Secara lebih rinci, dalam jurnal lainnya Deil S. Wright (1974) juga menjelaskan sub unsur yang membangun kelima unsur khusus yang mempengaruhi hubungan antar daerah tersebut. Secara ringkas antara lain: multiple entities, interaction of officials, communiation, all Public official dan policy emphasis

\section{METODOLOGI PENELITIAN}

Penelitian ini berlangsung selama 6 bulan di kawasan metropolitan Banjar Bakula. Penelitian ini dilakukan secara kualitatif. Untuk mendapatkan data primer dilakukan dengan wawancara mendalam, diskusi kelompok terfokus. Sumber datanya adalah pejabat pemerintah yang terkait dengan kerja sama pengelolaan TPA Regional: Dinas kebersihan dan pertamanan kabupaten/kota, Bappeda kabupaten/kota, Direktorat Pengembangan Penyehatan Lingkungan Pemukiman, dan Badan Koordinasi Kerjasama Pembangunan Kawasan Perkotaan Metropolitan Banjar Bakula. Selanjutnya data sekunder yang diperoleh dari lokus kawasan Banjar Bakula digunakan untuk mendukung temuan.

\section{PEMBAHASAN}

Hubungan antar susunan pemerintah dalam pengelolaan Tempat Pemerosesan Akhir Sampah Regional. 


\section{Pertama, Multiple Entities (National, Provincial and Municipalities).}

Peran pemerintah pusat dalam kebijakan pembangunan terlihat dari adanya Undang-undang (UU) Nomor 25 Tahun 2004 tentang Sistem Perencanaan Pembangunan Nasional, Rencana Pembangunan Jangka Menengah Nasional (RPJMN) tahun 2015-2019, dan juga program Masterplan Percepatan dan Perluasan Pembangunan Ekonomi Indonesia (MP3EI) khususnya di Kalimantan Selatan.

Terkait kerja sama pembangunan TPA Regional di kawasan Metropolitan Banjar Bakula pemerintah pusat tidak terjun pada tataran operasional baik dalam penyusunan regulasi maupun memfasilitasi kerjasama pembangunan dan pengelolaan TPA Regional. Sedangkan pada tingkat provinsi, peran pemerintahan sangat signifikan karena telahmelakukan studi kelayakan dalam penentuan tempat yang strategis bagi penyediaan TPA Regional dikawasan ini.Hasil studi kelayakan menetapkan Kota Banjarbaru menjadi pilihan yang ideal karena telah memenuhi persyaratan bagi TPA regional. Sedangkan peran pemerintah kabupaten/kota sebatas menyetujui dan memfasilitasi perencanaan yang telah dibuat oleh pemerintah provinsi.

\section{Kedua, Interaction of Officials}

Interaksi aparat publik dalam hubungan kerjasama antar daerah menjadi penting, karena akan menentukan keberlangsungan dari suatu kerjasama tersebut. Interaksi tersebut dilihat dari empat sub unsur yaitu, perilaku, kepercayaan, persepsi dan preferensi dari aparatur yang terlibat. Adapun gambaran keempat sub unsur tersebut sebagai berikut:

a. Asfek perilaku, ruang lingkup pekerjaan pemerintah pusat sangat luas, sehingga pemerintah pusat melihat permasalah daerah secara umum dan kecendrungan perilakunyakurang responsif. Prilaku aparatur pemerintah provinsi cenderung lebih responsif karena permasalah pembangunan yang yang terjadi bersifat lintas yurisdiksi kabupaten/kota dan menjadi kewenangannya. Sementara perilaku pemerintah kabupaten/kota cenderung kurang responsif dan pasif, hal ini disebabkan adanya perbedaan tingkat kepentingan diantara pemerintah kabupaten/kota dalam pembangunan TPA Regional dan perbedaan pemahaman tentang arti pentingya keberadaan TPA Regional tersebut.

b. Asfek kepercayaan, Kepercayaan yang rendah ditunjukkan pemerintah pusat kepada daerah karena pemerintah pusat melihat sikap daerah cenderung pasif dan kurang memiliki inisiatif. Sedangkan kepercayaan Pemerintah Provinsi cenderung kurang terhadap pemerintah pusat karena kehadiran intervensi pemerintah pusat akan dirasakan menggangu kewenangan provinsi. Intervensi pusat lebih kepada sisi pembiayaan maupun pembinaan teknis bukan pada kewenangan kebijakan. Kepercayaan Provinsi terhadap Pemerintah Kabupaten/kota sangat rendah, dikarenakan pemerintah kabupaten/kota dalam menghadapi berbagai permasalah sering secara langsung berhubungan dengan pemerintah pusat yang seharusnya dapat melakukan koordinasi melalui pemerintah Provinsi. Disisi yang lain kepercayaan kabupaten/kota terhadap pemerintah provinsi kurang baik terlihat dari anggapan mereka yang menganggap bahwa provinsi belum mampu mewakili kepentingan mereka.

c. Asfek persepsi, Pemerintah pusat dan Pemerintah Provinsi melihat kerjasama antar daerah sebagai solusi untuk mengurangi beban daerah dan menjadi solusi atas permasalahan sampah di kawasan ini. Kota Banjarmasin melihat kerjasama pengelolaan TPA Regional ini sangat membantu, karena kondisi tanahnya yang berawa yang tidak ideal bagi pengelolaan sampah dengan baik. Bagi Pemerintah kabupaten Banjar keberadaan TPA Regional tidak mempengaruhi mereka, karena mereka telah memilik tempat pemerosesan akhir sampah yang baik. Sedangkan Pemerintah Kota Banjarbaru menganggap kerjasama ini akan menambah beban mereka terkait dengan dampak "bau" dan kerusakan jalan bagi kota ini.

d. Asfek preferensi kebijakan. Pemerintah pusat melihat isu pembangunan TPA Regional di kawasan Metropolitan Banjar Bakula secara umum yang terlihat dari dikeluarkannya UU RI No: 18 tahun 2008 Tentang Pengelolaan Sampah. Dalam prakteknya implementasi UU ini 
belum berjalan dengan baik. Pada level provinsi, kerjasama dalam pembangunan dan pengelolaan TPA Regional belum menjadi prioritas, karena terjadinya penolakan oleh Kota Banjarbaru setelah disepakati terkait TPA Regional. Dan selama ini Pemerintah Kota Banjarbaru tidak memperoleh bantuan alokasi dana terkait pengelolaan sampah baik dari Pemerintah Pusat dan Pemerintahan Provinsi.Di level Kota Banjarbaru preferensi kebijakan terhadap kerjasama antar daerah dalam pembangunan TPA Regional masih lemah, hal ini terlihat dari sikap pemerintah daerah cenderung inferior dan tidak responsif menyikapi hal tersebut dan bahkan menolak TPA Regional di kota ini.

\section{Ketiga, Communication (Continous and Cumulative)}

Komunikasi antar pejabat daerah dalam kerjasama adalah sangat penting. Interaksi yang dilakukan antar para pejabat daerah secara teratur menunjukkan terjadinya komunikasi yang berlanjut. Hal ini dapat dilihat dari: kontak dari hari ke hari, hubungan kerja yang berjalan dan pola kumulatif yang terbangun.

Komunikasi rutin antar susunan tingkat pemerintah dalam mewujudkan TPA Regional di Kawasan Metropolitan Banjar Bakula relatif jarang dilakukan, selain tidak adanya jadwal yang dibuat juga keterbatasan dana operasional sehingga pembahasan terhadap pembuatan dan pengelolaan TPA Regional menjadi terhambat. Tidak fokusnya pembahasan yang dilakukan serta bedanya peserta forum komunikasi juga menghambat pembangunan TPA Regional.

Hubungan kerja antar pemerintah belum ada hanya sebataspada Memorandum of Understanding (MoU) yang menetapkan Kota Banjarbaru menjadi tempat TPA Regional di Kawasan Metropolitan Banjarbakula. Pola kumulatif yang dilakukan pemerintah provinsi Kalimantan Selatan dengan pemerintah kabupaten/kota di kawasan metropolitan Banjar Bakula belum mendapatkan hasil yang baik.

\section{Keempat, All Public Officials (Administrators)}

Pengaruh parlemen/legislative baik di tingkat pusat, provinsi maupun kabupaten/kota dalam proses kerja sama antar daerah memiliki peran yang strategis. Hal ini terjadi karena dalam sistem pemerintahan di Indonesia fungsi anggaran dan regulasi menjadi kewenangan dari pihak legislatif. Di tingkat pusat, keaktifan anggota legislatif pada dasarnya terkait dengan aspirasi yang mereka wakili dan kebutuhan untuk peningkatan elektabilitas. Anggota legeslatif terkait dengan tugas dan fungsinya seringkali membawa isu ke tingkat pusat dan memperjuangkannya pada proses penganggaran, isu tersebut ditangani pemerintah dengan sumber dana dari Anggaran Pendapatan Belanja Negara (APBN). Perjuangan dari anggota legislatif ini dapat merubah perencanaan anggaran yang telah dilakukan oleh pihak eksekutif.

Sedangkan peran eksekutif dalam kerjasama antar daerah juga memiliki kendala yang sama. Peran eksekutif di tingkat pusat jelas sangat penting namun selama ini justru belum ada kejelasan siapa melakukan apa dan siapa yang mengendalikan pelaksanaan kerjasama di kawasan Metropolitan Banjar Bakula di Provinsi Kalimantan Selatan, khususnya pelaksanaan TPA Regional. Pemahanan Kerjasama antar daerah dan implementasinya di tingkat pusat dan provinsi mempunyai perbedaan sudut pandang terkait siapa yang bertanggung jawab penuh terhadap kerjasama tersebut. Di Kawasan Metropolitan Banjar Bakula pelaksanaan pembangunan TPA Regional di tangani oleh 2 (dua) kementrian yaitu Kementrian Pekerjaan Umum dan Kementrian dalam negeri. Di tingkat Provinsi pihak eksekutif belum mampu menggerakkan pemerintah kabupaten/kota untuk fokus dalam kerjasama antar daerah yang lebih efektif untuk menyelesaikan permasalahan TPA Regional. Sementara di tingkat kabupaten/kota, kesulitan eksekutif yang terjadi selama ini adalah perbedaan kepentingan antar kabupaten/kota. Perbedaan pemahaman dan sikap ego pemerintah dapat membawa kendala dalam proses kerjasam antar daerah. 


\section{Kelima, Policy Emphasis}

Pada poin ini dilihat bagaimana perhatian pemerintah terhadap kebijakan khususnya dari sisi fiskal. Dalam hal ini perlu dilihat dampaknya terhadapanggaran khususnya dari: isu keuangan (kemampuan anggaran), dukungan politis, dan dampak pada ruang lingkup kebijakan lainnya.

Pada tingkat kebijakan pemerintah pusat terkait kawasan Metropolitan Banjar Bakula belum ditindaklanjuti dalam kebijakan teknis/operasional termasuk anggaran sebagai konsekuensi kebijakan tersebut. Hal ini menyebabkan kerjasama pembangunan dan pengelolaan TPA Regional belum berjalan secara optimal karena minimnya dukungan teknis dan dana.

Pada level Pemerintah Provinsi alokasi danadalam menyelenggarakan urusannya sudah seharusnya dianggarkan dalam APBN. Namun pada kenyataannya pengalokasian dana untuk kerjasama tersebut belum berjalan secara lancar. Aturan main secara teknis lapangan yang seharusnya mengikuti suatu kebijakan yang lebih operasional memang menjadi sorotan daerah. Seharusnya kebijakan teknis yang bersinggungan dengan kepentingan fiskal apalagi sifatnya antar daerah harus diikuti oleh kebijakan operasional lainnya yang merupakan penjabaran dari kebijakan makro.

\section{Model hubungan antar daerah dalam melakukan kerjasama}

Pembangunan TPA Regional di kawasan Metropolitan Banjar Bakula termasuk urusan konkuren yang melibatkan pemerintah pusat, provinsi dan kabupaten/kota mulai dari perencanaan, pembiayaan, pelaksanaan dan pengawasan. Oleh karena itu perlu adanya sinergi dalam manajemen antar pemerintah sehingga pelaksanaan pembangunan dapat terlaksana dengan baik.

Berdasarkan hasil penelitian terlihat bahwa dalam pembangunan TPA Regional ini peran Provinsi sangat sentral, namun belum diimbangi dengan kemampuan pendanaan, serta pelaksanaan koordinasi yang baik, sementara pemerintah kota lebih bersifat menunggu dan tidak resfonsif. Kondisi ini berdampak kepada realisasi pembangunan TPA Regional menjadi terkendala dan lambat. Berikut ini gambar model hubungan yang terjadi dalam pembangunan TPA Regional di kawasan ini

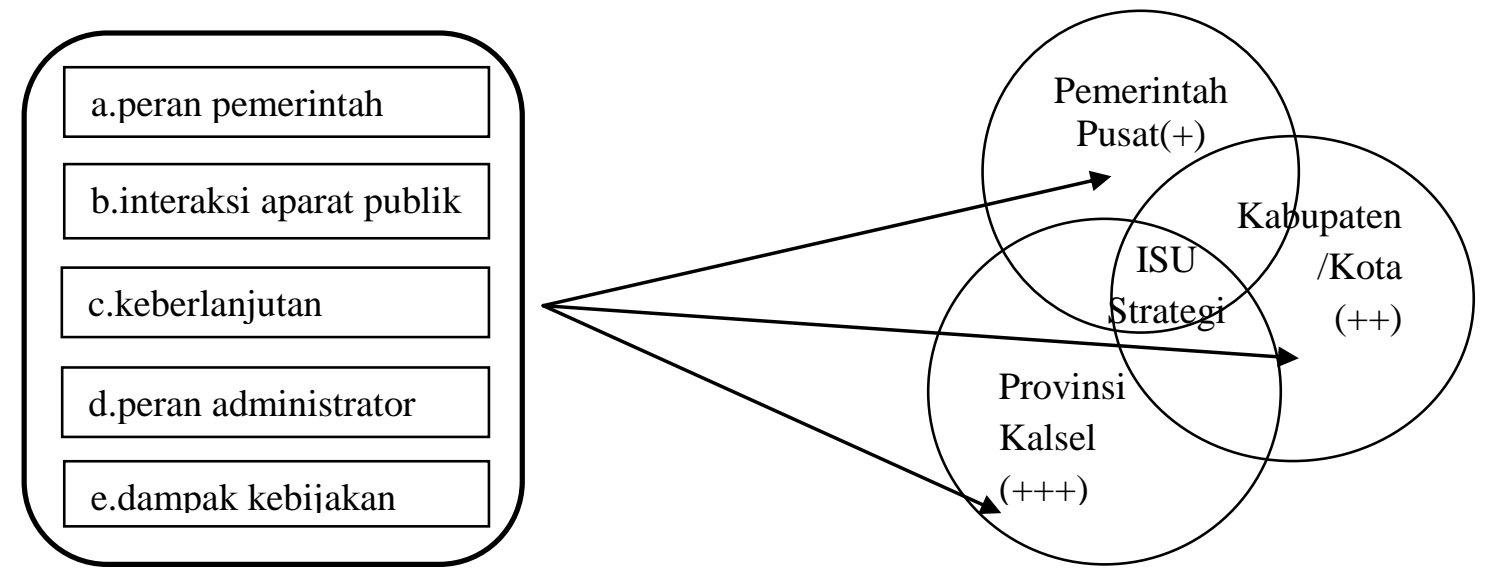

\section{Gambar :1 Model Hubungan Antar Pemerintah Saat Ini}

Gambar (+) menunjukkan bahwa pemerintah pusat dalam hubungan antar susunan pemerintah dinilai masih kurang kuat, padahal masalah TPA Regional,merupakan isu strategis daerah ini yang harus dicari solusinya. Sedangkan gambar (+++) menunjukkan peran aktif dari pihak pemerintah Provinsi dalam hubungan antar susunan pemerintah, sedangkan gambar (++) menunjukkan peran Kabupaten/Kota yang sangat terbatas/belum optimal. 
Ketidak seimbangan peran antar pemerintahan dapat dikurangi dengan kesetaraan kewenangan diantara susunan pemerintahan tersebut sehingga beban dari pemerintah provinsi dapat dikurangi sehingga keterlambatan dalam implementasi program pembangunan TPA Regional tersebut dapat dikurangi.

Salah satu dari beberapa misi pemerintah Provinsi Kalimantan Selatan adalah pembangunan prasarana dan sarana publik, misi pemerintah tersebut tentu tidak terlepas dari isu-isu strategis yang dihadapi daerah ini. Isu strategis tersebut terkait dengan hubungan kerja sama antar pemerintah daerah di kawasan Banjar Bakula. Kawasan Banjar Bakula adalah kawasan strategis provinsi dan berpotensi menjadi kawasan strategis nasional. Kawasan Banjar Bakula ini juga sudah menjadi kawasan metropolitan, sehingga penataan kawasan ini menjadi begitu penting. Didalam penanganan pembangunan antar daerah kabupaten/kota dalam provinsi dilakukan oleh pemerintah Provinsi sebagai mana diatur di dalam UU RI No 23 Tahun 2014 pasal 364 ayat 4 Undang-Undang tentang Pemerintahan Daerah disebutkan bahwa apabila ada kerja sama wajib antar daerah dalam satu provinsi yang tidak dilaksanakan oleh daerah kabupaten/kota, gubernur sebagai wakil pemerintah pusat dapat mengambil alih pelaksanaannya.

Salah satu isu strategik yang terjadi dikawasan ini adalah tempat pemerosesan akhir sampah regional. Kondisi ini terjadi karena kabupaten Barito Kuala dan Kota Banjarmasin yang merupakan dua dari lima daerah di kawasan Banjar Bakula yang menghadapi kendala dalam pemerosesan akhir sampahnya, Karena isu ini memiliki dampak eksternalitas sehingga harus melibatkan kabupaten/kota yang ada di kawasan ini. Kerja sama antar pemerintah daerah dikawasan ini menjadi kunci bagi penyelesaian masalah yang dihadapi di kawasan Metropolitan Banjar Bakula. Hubungan didalam pelaksanaan pembangunan yang melibatkan beberapa pemerintahan diatur didalam perundang-undangan yang berlaku. Sejalan dengan itu Wright (1982) mengatakan untuk mencapai hubungan antar pemerintah perlu diperhatikan lima unsur khusus, unsur-unsur tersebut yaitu peran pemerintah, interaksi aparat publik, keberlanjutan komunikasi, peran administrator dan fokus perhatian pada kebijakan.

Gambaran berikut menyimpulkan bahwa suatu kerjasama yang terjalin dalam suatu wilayah akan berinteraksi menuju tujuan bersama walaupun, berada didalam yuridiksi yang berbeda. Terpenuhinya unsur unsur yang diungkapkan oleh Wright merupakan "Kunci" bagi keberhasilan hubungan antara pemerintah dalam melakukan kerja sama. Unit pemerintah apa saja yang terlibat didalam kerja sama tersebut, bagaimana interaksi antar pejabat yang terjadi, sampai sejauh mana keteraturan dan keberlanjutan interaksi yang terjadi, dukungan apa yang telah diberikan oleh administrator dan bagaimana fokus perhatian yang diberikan dari sisi fiskal dalam hubungan tersebut.

Peran pemerintah pusat sangat diperlukan didalam pembangunan infrastruktur perkotaan terutama terkait pembangunan TPA Regional di kawasan Banjar Bakula. Pemerintah Pusat sebagai Pembina yang dapat menerbitkan berbagai regulasi berupa penetapan Kawasan Banjar Bakula sebagai Kawasan Strategis Nasional, maupun sebagai fasilitator dan koordinator pembangunan. Keterlibatan ini dapat secara intensif dalam membantu menyelesaikan permasalahan secara operasional, selain itu juga pemerintah pusat dapat memberikan insentif terhadap kerjasama yang dilakukan antar daerah dan yang memiliki dampak eksternal bagi suatu kawasan.Keaktifan peran pemerintah juga telah disebutkan oleh Dwiyanto (2005:8) yang menekankan tentang redefinisi peran pemerintah dengan adanya demokratisasi, deregulasi dan privatiasi saat ini. Selain itu juga Osborne dan Gaebler (1992) yang menekankan peran negara lebih sebagai fasilitator atau supervisor dalam penyelenggaraan urusan publik.

Kerja sama antar daerah dalam pembangunan TPA Regional merupakan proses hubungan yang saling menguntungkan dan adanya kesamaan tujuan dari daerah-daerah yang melakukan kerjasama tersebut, mereka saling berinteraksi melalui suatu negosiasi dan tentu semua aktivitas tersebut didasari oleh adanya rasa saling percaya (Thomson .2007). 
Komunikasi juga menjadi faktor penting dalam melakukan kerjasama seperti yang di sebutkan oleh Ansell dan Gash, (2007) Komunikasi tatap muka dalam menghadapi strerotif masalah adalah cara yang selalu dianjurkan didalam literatur-literatur tentang kerjasama, dialog tatap muka merupakan kondisi yang diperlukan dalam kolaborasi. Oleh karena itu dialog langsung diperlukan bagi para pemangku kepentingan untuk mengidentifikasi peluang yang saling menguntungkan. Dialog ini merupakan inti dari proses membangun kepercayaan, saling menghormati, menciptakan pemahaman bersama dan membangun proses komitmen. Komunikasi yang tidak lancar menjadi penghambat dalam pelaksanaan pembangunan TPA Regional ini.

Berdasarkan UU no 23 tahun 2014 tentang Pemerintahan Daerah ada dua sub unsur yang terkait dalam kerja sama dan merupakan administrator, yaitu pejabat publik yang dipilih (elected officials) baik legislatif maupun eksekutif serta pejabat publik yang ditunjuk (appointed administrator) baik dari sisi aparat umum maupun aparat dengan fungsi khusus/profesional. Pada dasarnya pejabat publik yang dipilih oleh masyarakat baik di tingkat pusat, provinsi maupun di kabupaten/kota dalam proses kerja sama antar daerah mempunyai peran yang sangat penting karena pejabat publik tersebut tidak terlepas dari nuansa politik yang berpengaruh terhadap kebijakan yang diambil .

Dalam model teori Wright pola hubungan antar pemerintahan ada tiga model yaitu coordinate authority model, inclusive authority model dan overlapping authority model, dalam konteks kerja sama antar daerah di Kawasan Banjar Bakula model terdekat adalah overlapping authority model. Dalam model ini menunjukkan masing masing pemerintahan mempunyai bidang/urusan yang menjadi kewenangannya. Kedua masing-masing Pemerintahan memiliki wilayah otonomi atau wilayah yurisdiksi tunggal/independen dan yang ketiga terdapat wilayah tumpang tindih kewenangan yang berkaitan dengan urusan pemerintahan tertentu. Pada wilayah tumpang tindih inilah terjadi tawar-menawar (lobi/negosiasi) kewenangan dalam program/proyek).

Untuk memperoleh hasil yang lebih baik dalam hubungan antar pemerintah dalam pengelolaan Tempat Pemerosesan Akhir sampah (TPA) regional di kawasan ini peran pemerintah yang tidak seimbang perlu dilakuan proses negosiasi diantara pihak-pihak yang terlibat dalam pembangunan TPA Regional ini dapat di lakukan sehingga masalah sampah yang dihadapi oleh kabupaten Barito Kuala dan Kota Banjarmasin khususnya dan kawasan Banjar Bakula umumnya dapat terpecahkan. Oleh karena itu negosiasi terkait peran pemerintah, interaksi aparat publik, keberlanjutan komunikasi, peran administrator dan dampak kebijakan yang diperlukan dapat menemukan keseimbangan yang baru dan pembangunan TPA Regional dapat terwujud.

\section{SIMPULAN}

Berdasarkan hasil analisis dapat disimpulkan:

1. Pemerintah provinsi yang mempunyai kewenangan besar adalah aktor yang diharapkan dapat berperan lebih dalam mengatasi permasalan pembangunan TPA Regional dikawasan Banjar Bakula, sehingga hambatan ego kedaerahan yang dihadapi dapat teratasi

2. Kerja sama antar daerah menekankan tentang pentingnya interaksi antar aparatur pemerintah, interaksi tersebut dapat membangun kepercayaan dalam memenuhi kepentingan daerah. Dengan rasa saling percaya akan muncul kesamaan persepsi. Kesamaan persepsi tersebut dapat meningkatkan preferensi terhadap kebijakan yang diambil dalam pembangunan dan pengelolaan TPA Regional.

3. Penelitian ini merekomendasi dalam membangun model kerjasama antar daerah di kawasan Banjar Bakula diperlukan renegosiasi kewenangan antar daerah didalam 
melakukan pembangunan TPA Regional sehingga issu strategis dalam pembangunan dan pengeloaan sampah dapat direalisasikan.

\section{REFERENSI}

Ansell, Chris dan Gash, Alison. 2007. Collaborative Governance in Theory and Practice, Journal of Public Administration Research and Theory, JPART 18:543-571, Oxford University Press.

Dwiyanto, Agus, 2005, Mewujudkan good governance melalui pelayanan publik, Yogyakarta: Gadjah Mada University Press.

Hulst R., A. van Montfort, A. Haveri, J. Airaksinen, J. Kelly. 2009. Institutional shifts in intermunicipal service delivery, Public Organization Review 9, 263-285.

Kurtz, Thomas S. 2006. Intergovernmental Cooperation Handbook, Governor's Center for Local Governments Services, Dep. Of Community and Eco. Development Commonwealth Keystone Building 400 North Street, 4Th, Floor Harrisburg, Pennsylvania, sixth Edition.

London, Nigel, 2013, Sebuah Tinjauan Tentang Sektor Manajemen Persampahan Indonesia, Jurnal Prakarsa Infrastruktur Indonesia Edisi 15 Oktober 2013.

Muthalib, MA., Mohd. Akbar Ali Khan. 1982, Theory of Local Government, New Delhi: Starling publisher Private Limited

Osborne, David \& Gaebler Ted. 1992. Reinventing Government Addison-Wesley Publ. Co., 427 pages

Swianiewics, Pawel. 2011. Working Together: Intermunicipal Cooperation in Five Central Eropean Countries. Open Society Fondation. Budapest.

Tarigan, Antonius. 2009. Kerjasama Antar Daerah (KAD) Untuk Peningkatan Penyelenggaraan Pelayanan Publik Dan Daya Saing Wilayah Bulletin Tata Ruang, Maret - April (Edisi Meningkatkan Daya Saing Wilayah).

Thomson, Ann Marie and James L. Perry. 2006. Collaboration Processes : Inside the Black Box, paper presented on Public Administration Review; Dec 2006; 66, Academic Research Library pg.20

Wright, Deil S. 1982. Understanding Intergovernmental Relations Second Edition. Brooks/Cole Publishing Company. California, pp: 29-40 